\title{
Environmental and Mineralogical Studies of the Sabkhas Soil at Ismailia_-Suez Roadbed, Southern of Suez Canal District, Egypt
}

\author{
Mohamed M. El-Omla ${ }^{1}$, Hamdy A. Aboulela ${ }^{2}$ \\ ${ }^{1}$ Geology Department, Faculty of Science, Suez Canal University, Ismailia, Egypt \\ ${ }^{2}$ Marine Science Department, Faculty of Science, Suez Canal University, Ismailia, Egypt \\ Email: aboulel1_004@yahoo.co.uk
}

Received April 5, 2012; revised May 15, 2012; accepted May 25, 2012

\begin{abstract}
Eight surface sabkha soils samples were collected from Ismailia—Suez roadbed, southwestern of Suez Canal district. Sedimentological and mineralogical analyses were conducted using grain size; X-ray diffraction and Scanning Electron Microscopy (SEM). Grain size analysis indicates high contents of fine sand and mud as well as presence of salts. X-ray diffraction; Scanning Electron Microscopy (SEM) and EDAX tool clarified that the sabkha soils are enriched by quartz, sulfate minerals (gypsum, anhydrite), carbonate minerals (calcite-dolomite-aragonite), chlorides (halite and bischofite), and clay minerals. The results elucidate that the appearance of sabkha deposits and their distribution in the study area are controlled mainly by the content of water soluble salts through parent materials; ground water table; subsurface structural; and physiographic features for instance surface relief or topography; and human activity.
\end{abstract}

Keywords: Suez Canal; Sabkha Soil; Grain Size; SEM and X-Ray Diffraction Analyses

\section{Introduction}

A sabkha is defined as a flat area that is prone to periodic inundation and evaporate deposition, and dominated by carbonates or sulphates. As a general, the sabkha deposits are common in several arid areas of the World. It is controlled mainly by the content and distribution of water-soluble salts through parent rocks [1-3]. Sabkha deposits are one of the Arabic expressions to describe recent coastal sediments with a high salt content. Sabkhas may occur inland or as coastal sabkha, which are common in arid shallow-shelf environments. Sabkhas are developed in response to different environmental conditions, e.g. deflation of sediment surfaces, sediment accumulation in a lagoon, or by a combination of both processes [4,5]. Nowadays, the governmental authorities undertook great efforts for the reconstruction of the Suez Canal region (Figure 1), where Suez Canal region takes the precedence over the other region in northern Egypt due to its considerable potentialities and strategic location. Previous multidisciplinary studies of geo-environmental and hydrogeology carried out at Suez Canal region allowed the delimitation of several zones taking into account environmental features and the impact of different anthropogenic actions over each one of them [6-12]. Recently, the sabkha deposits and their distribution in
Suez Canal district is remarkably raised and causing harmful impact on vegetations and agriculture lands, subsidence in many regions in particular at the north-southwestern of Suez Canal district and losses in properties coastal sediments roadbeds [13-15]. These effects increase gradually to southwestern of Suez Canal district in particular towards Ismailia-Suez roadbed. However detecting the factors affecting the salinity of some recent sediments at the above mentioned roadbed are still not enough to construct a sound basis for future development overall Suez Canal region.

The present study aims to assess the physiographic features of sabkha deposites and their distribution pattern at the southwestern of Suez Canal district. Grain size analyses, mineralogical analyses using Scanning Electron Microscopy (SEM), EDAX, and X-ray diffraction techniques of the recent surfacial sabkha soils were done.

\section{The Study Area}

The eight sabkhas sites are located near Ismailia—Suez roadbed of Suez Canal district; bounded by latitudes $29^{\circ} 95^{\prime} \mathrm{N}$ to $30^{\circ} 40^{\prime} \mathrm{N}$ and longitudes $32^{\circ} 15^{\prime} \mathrm{E}$ to $32^{\circ} 40^{\prime} \mathrm{E}$. It is represents the southern western district of Suez Canal (Figure 1). The area under investigation comprises two sites, one belongs to Ismailia governorate while, and the 


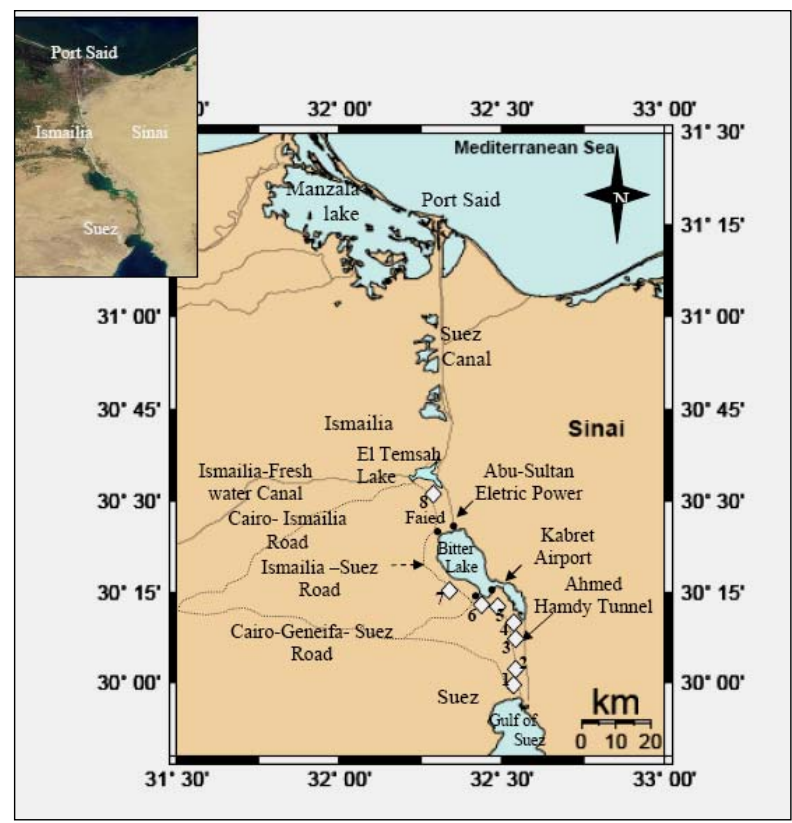

Figure 1. Location map of sabkha sites in the study area. Sabkha sites: 1: Entrance of Suez; 2: El Gnayen village; 3: Arab El Dabour village; 4: Ahmed Hamdy tunnel zone; 5: South of El Shallufa village; 6: North of El Shallufa village; 7: Genifa area; and 8: Enternce of Ismailia.

other belongs to the Suez governorate. There are several roads to reach the study area as Ismailia-Suez; CairoSuez; Cairo-Ismailia; and Cairo-Geniefa highways (Figure 1). The study area includes a variety of anthropogenic activities as power plants, military sites, tourist villages, tunnel, irrigation canal, agricultural lands, industrial centers, and pipelines as well as new urbanizetion and village population zones cause variable environmental impacts on its environs. The climate of the study area is markedly arid, with an average annual rainfall of less than $350 \mathrm{~mm}$. Extreme temperatures values vary from $15^{\circ} \mathrm{C}$ to $42^{\circ} \mathrm{C}$ and dry north-westerly winds are common as well as the evaporation ( $850 \mathrm{~mm} /$ year) as pointed by [15].

\section{Regional Geomorphologic and Geology}

The geomorphologic properties greatly affect the hydraulic conditions of the shallow aquifer in the study area. It is located on the northern and northeastern slopes of structural and topographical highs at the study area and its environs forming a belt extending from G. Shabraweet in the east looking to the Bitter lakes, and west limiting the eastern margin of the Nile delta. The highest elevation contours are located to the southwest of the area forming the water shed belt, whereas the lowest relief is marked by the inland lakes and the shallow water pools that separate the cultivated lands and sandy plains in a linear pattern distribution running parallel to Ismailia
Canal. Sand accumulations sometimes as dunes bound these pools and separate from the gravelly and sandy slopes in the west as suggested by [12]. The natural Hydrogeological conditions of the study area are poor due to the saline water content of the underlying sediments, which are characterized by poor hydraulic properties and high salt content [7]. In addition to, groundwater at the study area and its environs is mainly saline and has low recharge rates in particular at northern zone of the study area. The source of recharge of the shallow groundwater is mostly attributed to continuous seepage from the surrounding irrigated lands and surface water supplies [12]. The north-southwestern of Suez Canal district face variation in groundwater table related to topographic gradient as suggested by [16]. He pointed that, the hydromorphological environments and sediments of the northern western environs of Suez Canal region characterized by relative low land area less than 10 meters above sea level (asl.) and low water table at about 4 - 5 meters above sea level, and deltaic loamy sand deposits. The southern western environs of Suez Canal region is characterized by high land area with high topographic gradient, water table is relatively high more than 10 (asl.).

The regional geology of the study area and its environs was the subject of many investigations since it forms hydro-morphological environment; geomorphological; tectonic setting and framework as well as structural unit in the Suez Canal region. In view of the available literature on the regional geology of Suez Canal region such as those published as [6-8,12,16-19]. It can be stated that: The southwestern of Suez Canal district is a part of large tilted platform in northern Egypt that extends from east Sinai into the westernmost oases of the northern part of the western desert of Egypt. The study area and its surroundings occupy a semi-flat terrain exception of the area to the south where the high topographic land rises up towards the southern mountain as an example at G. Genifa, by average $(234 \mathrm{~m})$ above sea level and G. Shabraweet by average $(226 \mathrm{~m})$ above sea level. Numerous wadies drain in the study area, are filled with alluvial deposits. The most important wadis areas are Wadi El Ashara, Wadi Yasara, Wadi Al Agrama, and Wadi El Tumilat as shown in Figure 2. The surface soil in the study area is nearly flat with ripple marks. It is covered by an extensive sedimentary clastics and nonclastic accumulation, alluvial deposits ranging from Oligocene to Quaternary age [13]. The surface lithology of the study area and its environs is of a simple type. The rocks consist of unconsolidated Quaternary sediments with varying thickness. The Quaternary deposits exhibit more than 200 meter covering of braided river sediments to the north and fan type deposits to the east at valley mouths [14]. The Miocene bed rock exposures southward 


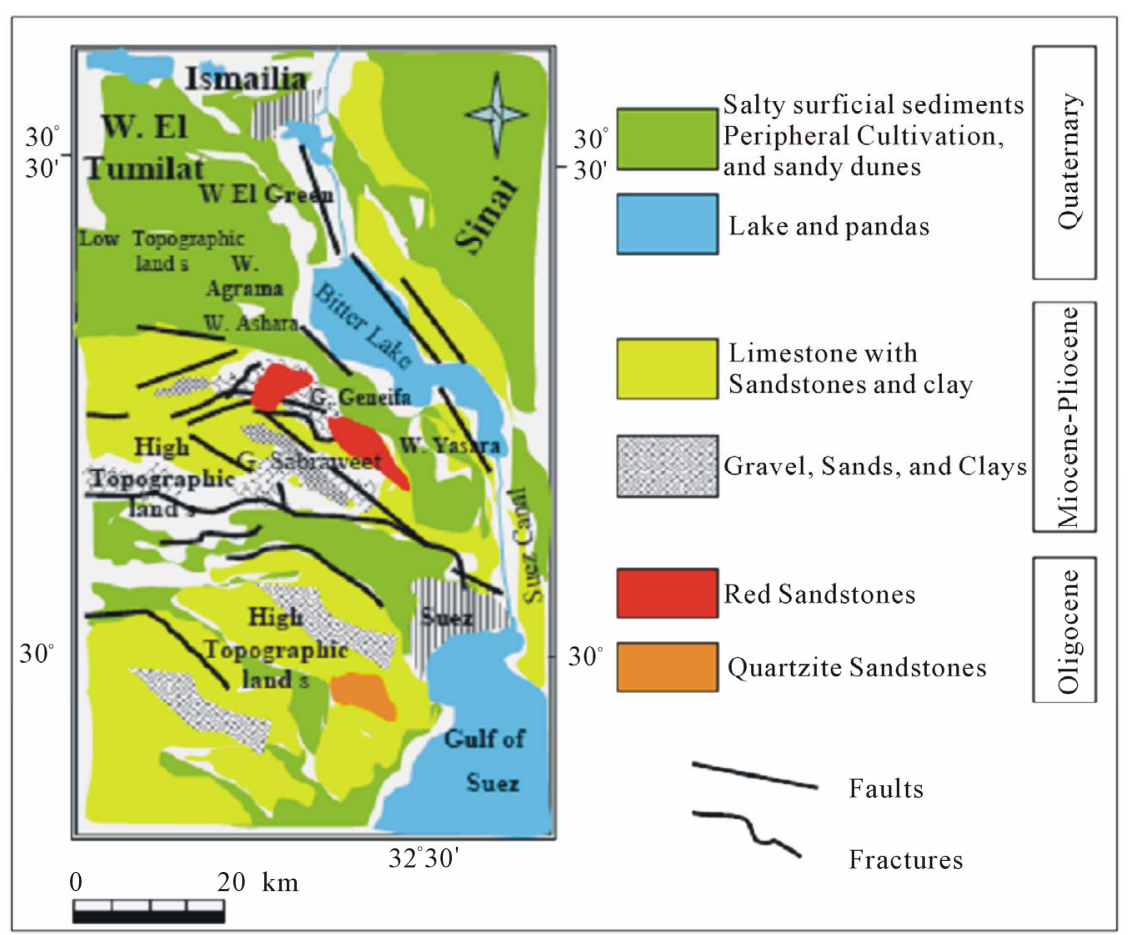

Figure 2. Simplified geological map of study area and its vicinity (modified after El Said, 1962; El Shazly, et al., 1975, and Geriesh, 1999).

is represented by two main units, lower and upper ones. The Lower one is composed of sandstone, clay and limestone. Upper one composed of white limestone with some intercalations of marl and clay limestone belongs mainly to chalky, coralline argillaceous and fossiliferous type. Fine clastic mud facies are well developed in the shallower horizons of Wadi Al Agrama and El Tumilat plain, running in the E-W direction towards Timsah Lake. They usually consist of fine to silty sands, sometimes calcareous to slightly gypsiferous, possibly this facies represents the laterally extensive flood plain of the El Tumilat River. This is further evidenced by the presence of plant remains and carbonaceous matters. Depression inland represents the sediments filling the shallow depressions including Lake El Temsah and Bitter lakes. The sediments in the upper horizons of these depressions consist of sand, clay, and gypsum bands. The subsurface geological and geophysical studies for the deeper horizons at the study area show two distinct sedimentary units lower are clay free sand unit. This includes coarse grained sands, while the upper sediments show clay intercalations with fine sands and silt sized grains [18]. The area under investigation is completely covered by thick evaporates deposits of Quaternary sediments that possibly mask earlier tectonic deformations.

\section{The Physiographic Features}

Based on the studied sabkhas sites and their distribution pattern as well as various physiographic features, two horizons can be conducted at the north-southwestern of Suez Canal district. Descriptions of these horizons are presented as the follows:

Northern Horizon: This horizon is characterized by semi-flat area lying to north of the Ahmed Hamdy tunnel zone. The northern western horizon stretch is occupied by four sabkha sites; it is located at entrance of Ismailia, Genifa area, North El Shallufa village and South El Shallufa village, respectively (Figure 1). The north horizon is occupied by salt and evaporates deposits, desert plants, agricultural activities and a low relief with width extensions area.

Southern Horizon: It represents the southern western most part of the study area, lying in southern Ahmad Hamdy tunnel. The southern horizon stretch is occupied by four sabkha sites; it is located at Ahmed Hamdy tunnel zone, Arab El Dabour village, El Ganayen village, and entrance of Suez respectively (Figure 1).

The assessment of various physiographic features at sabkha sites shows that, the two mentioned previously horizons and their environs include a variety of features and geohazards such as agricultural land destruction with soil salt concentrations features as shown in (Plates 1 and 2). In addition, the treatment of agricultural sewage unfiltered of agricultural lands to prevent soil salt concentration noticed in both horizons as trenches at Arab El Dabour village (Plates 1(e) and (f)). Table 1 shows the 

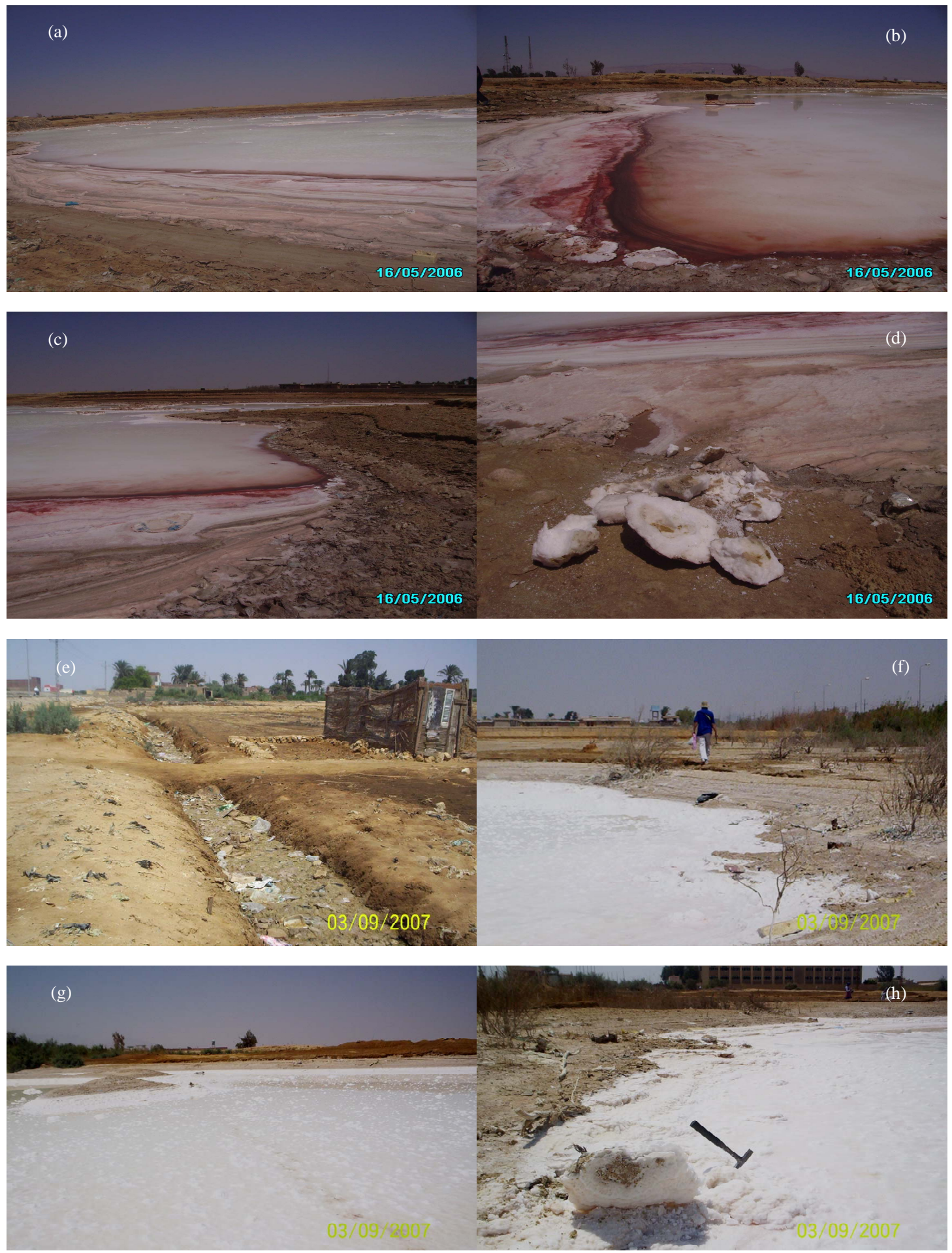

Plate 1. Photos showing various physiographic features as agricultural land destruction and treatment of agricultural sewage unfiltered (e) and (f); and hyper saline deposits of sabkha site at southern horizon. (a) and (b): Entrance of Suez; (c) and (d): El Ganayen village; (e) and (f): Arab El Dabour village; (g) and (h): Ahmed Hamdy tunnel zone.

location, average distribution pattern area and physiographic features of sabkha sites at the study area. There are primitive treatment efforts exerted by the inhabitants mainly in the northern and southern horizon, observed during field reconnences, as digging wells and trenches. In the northern and southern horizons, the salt affecting sediments are those containing soluble salts in quantities (or qualities) sufficient to affect the growth of most crops. 

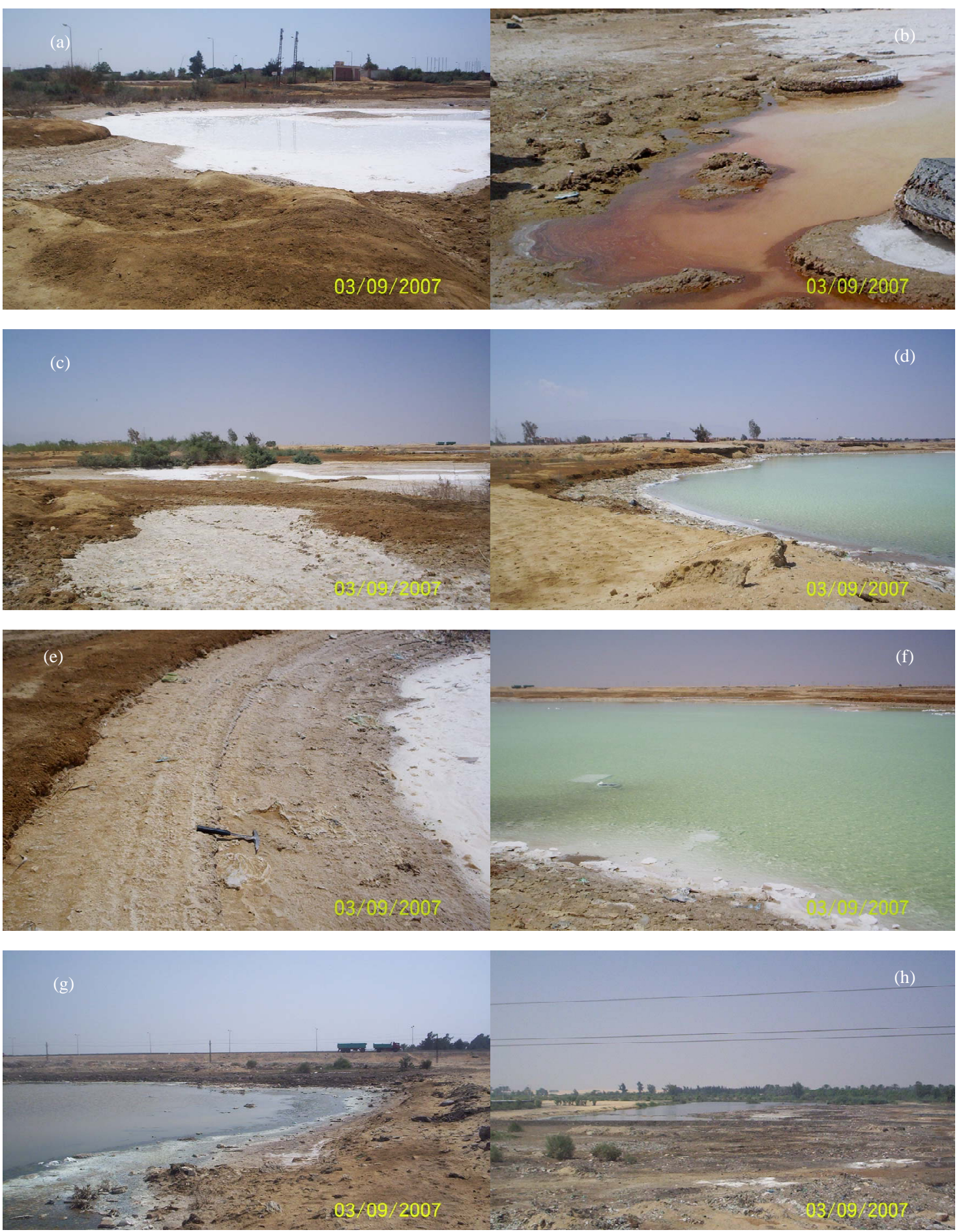

Plate 2. Photos showing various physiographic features as agricultural land destruction (h); and hyper saline deposits of sabkha site at northern horizon. (a) and (b): South El Shallufa village; (c) and (d): North El Shallufa village; (e) and (f): Genifa area; (g) and (h): Entrance of Ismailia.

Based on a lateral cross section at the study area (Figure 3), it can be noticed that, the sabkhas sites at the above mentioned horizons face variation in ground water table related to topographic gradient. Moreover, the effect of subsurface structural; surface or topographic relief and contradictory physiographic features of the northernsouthern horizon has a very significant role upon the salinity of the sediments. Also there are several factors involved in the distribution and appearance of sabkha deposits at study area such as parent rocks (limestone, 
Table 1. Locations of station sites, average distribution pattern area and physiographic features sabkha sites.

\begin{tabular}{cccc}
\hline Location of Sabkha Site & Station Sites & $\begin{array}{c}\text { Average Distribution } \\
\text { Pattern Area }\end{array}$ & Physiso-Geographic Feature of Sabkha Site \\
\hline South horizon of the study area & Entrance of Suez & $400-500 \mathrm{~m}^{2}$ & Sediment formation and hyper saline deposits \\
& El Ganayen village & $200-800 \mathrm{~m}^{2}$ & Soil salt and evaporates deposits \\
& Arab El Dabour village & $300-500 \mathrm{~m}^{2}$ & Soil salt and evaporates deposits \\
& Ahmed Hamdy tunnel zone & $200-400 \mathrm{~m}^{2}$ & Soil salt and evaporates deposits \\
North horizon of the study area & South El Shallufa village & $400-1000 \mathrm{~m}^{2}$ & Salt soil formation with agricultural land destruction \\
& North El Shallufa village & $400-1000 \mathrm{~m}^{2}$ & Salt soil formation with agricultural land destruction \\
& Genifa area & $400-500 \mathrm{~m}^{2}$ & Salt soil formation \\
& Entrance of Ismailia & $300-700 \mathrm{~m}^{2}$ & Salt soil formation \\
\hline
\end{tabular}

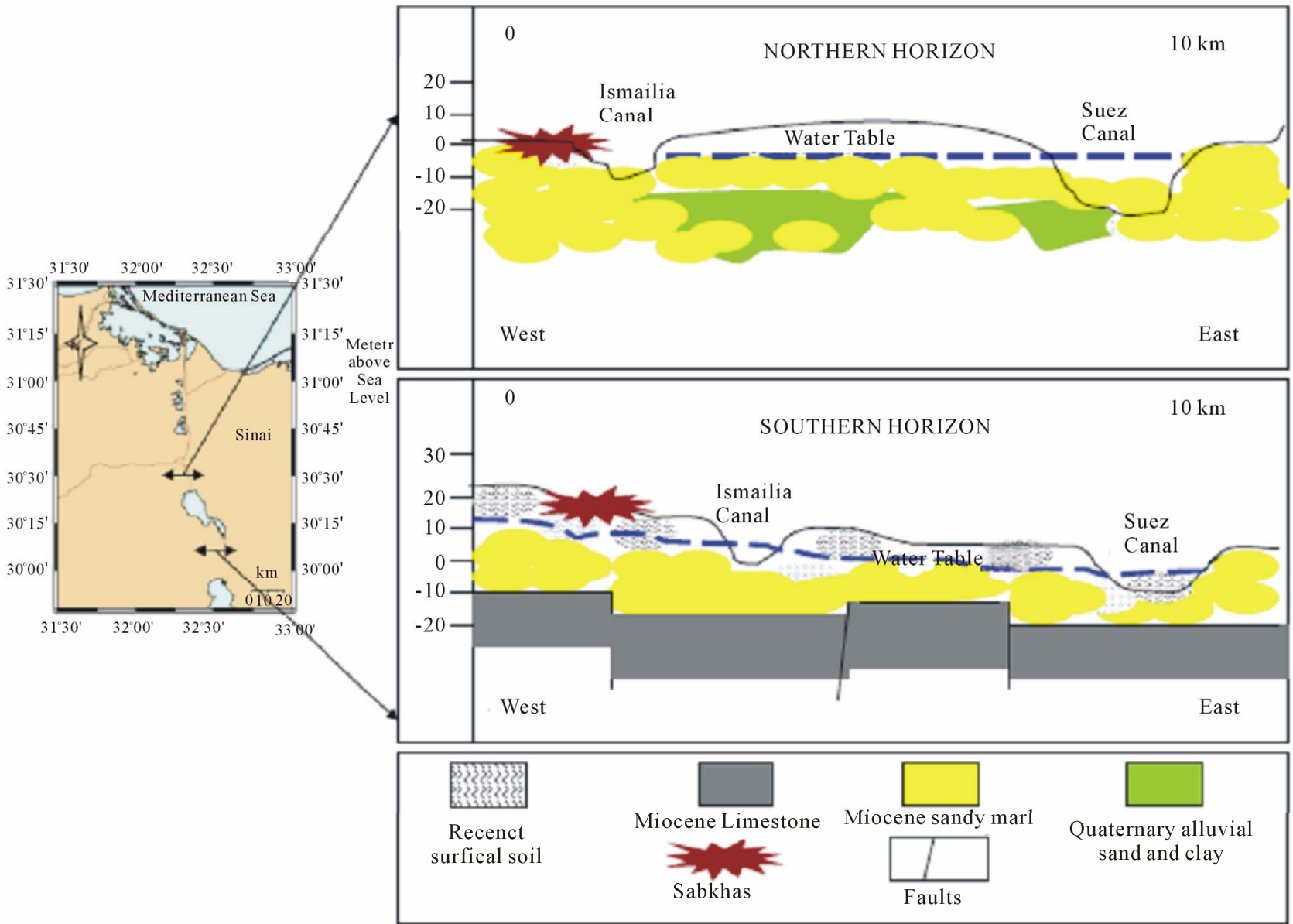

Figure 3. A latitude profiles with cross section showing various physiographic features of study area (compiled from Said, 1966; Geriesh, 1999; and studied sabkha sites).

sandstone and clay etc.); texture or lithology; and saline subsoil water.

\section{Methodology}

Several field trips were made to the southwestern of Suez Canal district to identify and verification the sabkha de- posits and collect samples during 2006-2007. Furthermore, two latitude profiles with cross section were planned to draw on the entire sides of the physiographic features of the investigation area. Based on the field observations, eight sabkha sites and their distribution pattern were identified in the study area. All of these sites 
are lying on north-southwestern horizon of Suez Canal district as the following: entrance of Ismailia, Genifa area, north of El Shallufa village, south El Shallufa village, Ahmed Hamdy tunnel zone, Arab El Dabour village, El Ganayen village, and entrance of Suez respectively (Figure 1).

Generally, the collected sabkha deposits consist mainly of sand, mud, organic matter and calcium carbonate as cement. Most of the collected samples contain salts crystals in varying percentages and need little time to be completely disaggregated by hand methods. The sample was dried at $100^{\circ} \mathrm{C}$ for 24 hours, and dilute hydrochloride acid (10\%) was used to remove calcium carbonates cement. They were heated in an oven to $140^{\circ} \mathrm{C}$ for about 24 hours and then wet sieved over a $63 \mu$ sieve. This removes all the salts present, so that the obtained sample would be free of calcium carbonate and salts crystals. To remove organic matter, Hydrogen peroxide (30\%) was added and the sample was left overnight. Then, the loss in weight was determined from the organic matter-free samples overnight. The sample was dried in an oven and weighed.

A preliminary microscopic examination was made using a binocular microscope to determine the state of aggregation of the constituent grains. The collected samples were washed, air dried and then dry samples were divided into two portions. The first portion was used for grain size distribution by dry sieving. The second portion was used for mineralogical analyses by X-Ray diffraction techniques and Scanning Electron Microscope (SEM). A mechanical sieves shaker and a stack of sieves were used to assess the percentage dry weight of sediment in each of 7 size classes: very coarse sand ( $>2 \mathrm{~mm})$, coarse sand ( $>1 \mathrm{~mm})$, medium sand $(>0.5 \mathrm{~mm})$, fine sand $(>0.25$ $\mathrm{mm})$, very fine sand $(>0.125 \mathrm{~mm})$, silt $(>0.063 \mathrm{~mm})$ and clay $(<0.063 \mathrm{~mm})$. After 15 minutes of shaking the sand retained in each sieve was weighed according to [20].

The XRD techniques were used for mineralogical identifications of the above sediments samples. The Xray diffraction method was used, and crystalline powder diagrams were obtained using a Rigaku D/max-2500 Pc $\mathrm{X}$-ray diffractometer apparatus. The X-ray profiles of the non-clay minerals in the silt and sand size fractions collected from the study area were identified by standard published methods [21]. The evaporate samples were examined in the range of $2 \phi=2^{\circ}-60^{\circ}$ under the following conditions: $\mathrm{Cu}$ tube operated at $\mathrm{Kv}=40, \mathrm{Am}=40$, diffractometer operated at scanning rate of $10 /$ minute and the chart recorder is 1o/centimetre. The evaporate intervals were identified according to their basic reflections as given in the ASTM cards index. In the present study, the diagenetic processes also have been studied for the collected samples using Scanning Electron Microscope (SEM) and EDAX tool in order to distinguish their petrographic features. These techniques housed deliberate for some sediments samples at the Nuclear Materials Authority, and the central laboratories of the Egyptian Geological Survey, Cairo, Egypt.

\section{Results and Discussion}

\subsection{Grain Size Analysis of Detrital Portion in the Sabkhas}

Mechanical analysis of the collected sediments shows that the majority of shallow sediments are unimodal sediments one-bar at Arab El Dabour village, El Ganayen village, North El Shallufa village, Genifa area, and entrance of Ismailia; bimodal sediments two-bar at Suez entrance but polymodal or scattered in nature at Ahmed Hamdy tunnel zone and South El Shallufa village as shown in Figures 4 and 5. Moreover, plots of the gravelsand-mud (silt plus clay), percentages on the corresponding ternary diagram of [20], are given in (Figure 6). The studied samples could be classified into three types agreeing very well with classification based upon histograms (Figures $\mathbf{4}$ and 5) and cumulative curves (Figures $\mathbf{7}$ and 8). The first type of collected sediments is mainly sand with scarce gravel and little mud (slit and clay). They are classified as gravelly muddy sand. The second type of sediments is characterized by considerable gravel content. It includes gravelly sand, and gravelly muddy sand. They are classified as muddy gravel. The third type of sediments is composed of admixture of sand and mud at different ratios. They are classified as muddy sand. Depending on the results in Figures 4-8, and using the cumulative curves nomenclature proposed by [22], the investigation collected sediments of sabkha sites revealed that, there are the deposition of river sand as well as weathering activity.

\subsection{Mineralogy and Petrographic Features}

The X-ray diffraction data of the collected sediments of all sabkha sites are listed in Table 2, and graphically presented on Figures 9 and 10. The scanning electron microscope (SEM) investigations are shown in Plates $\mathbf{3}$ and $\mathbf{4}$, and reflect the conserved mineral record that can be used to display the geochemical environment of the background of the sabkha sites in the past. The precipitation of evaporite minerals in sabkha sites is a complex process and is governed mostly by the balance of relative humidity and net evaporation. Further, the sequence of precipitation of different minerals at the sabkha sites and the sediments contains abundance of quartz, which is the most dominant detrital mineral in the sediments of the sabkha (Figures 4 and 5). This may be attributed to, the mentioned sabkha sites affected by eolian input from the sedimentary rocks that constitute the surface coverage of 

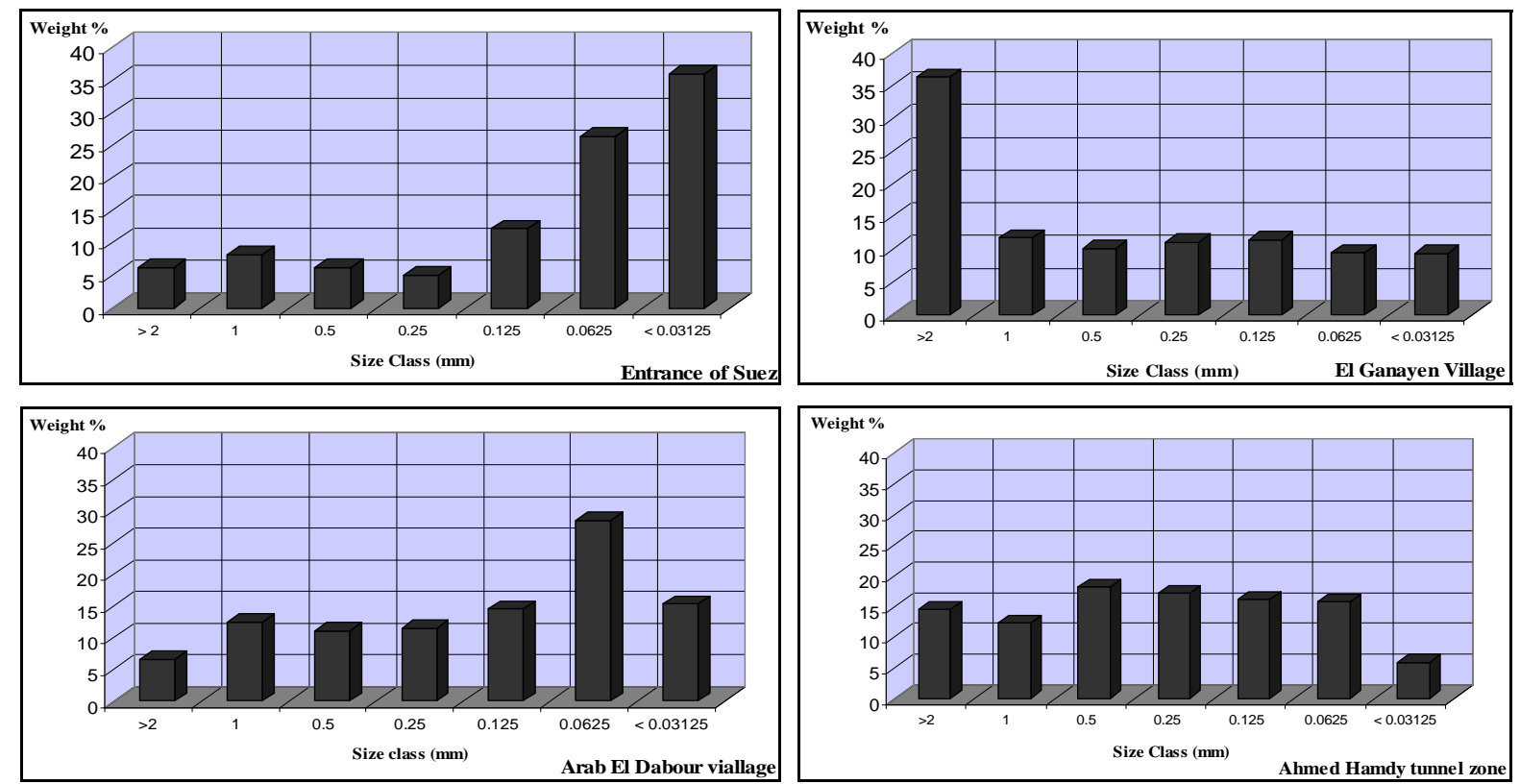

Figure 4. Histogram shows grain size distribution on southern horizon of the study area.
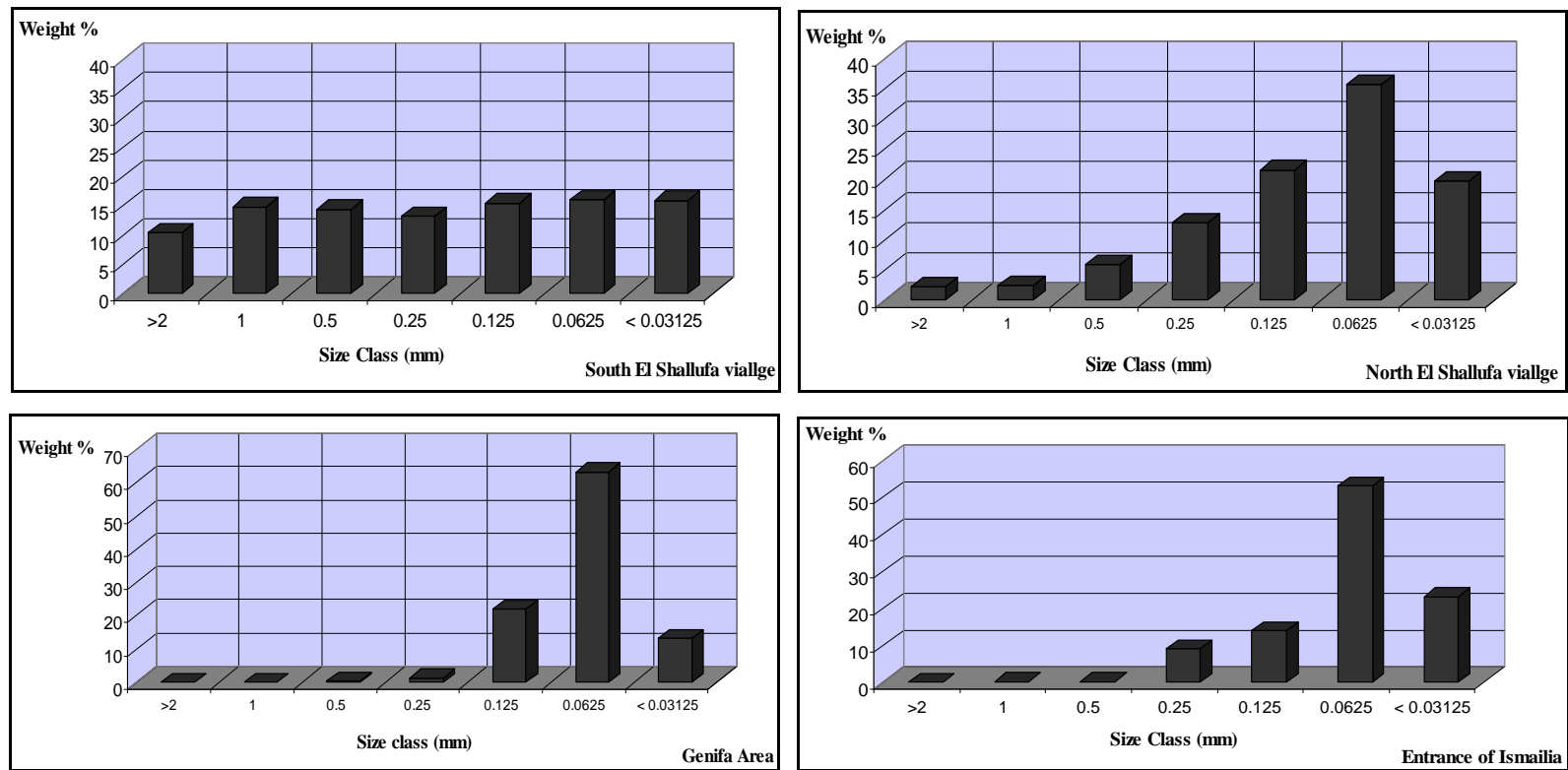

Figure 5. Histogram shows grain size distribution on northern horizon of the study area.

the adjacent land area. The erosion products are transported by intermittent surface wind.

Based on X-ray diffraction analysis, SEM and investigation of the mineral associations; the following results can be made: Quartz is the dominant constituent in most samples (Plate 3(a)). High $\mathrm{SiO}_{2}$ contents correspond to dominance of quartz (Plate $\mathbf{3 ( a )}$ ), and other clastic and terrigenous minerals, while variable $\mathrm{CaO}$ and/or $\mathrm{MgO}$ contents account for carbonates. Relative abundance of calcite and dolomite is reflected by $[\mathrm{MgO} /(\mathrm{MgO}+\mathrm{CaO})]$ ratio analyzing the general trends in the distribution of the main elements towards Ismailia Suez district roadbed.

The sands are mainly siliceous, and red or grey patches, which are more developed in the northern area of the district. The conserved mineral record can be used to display the geochemical environment of the background of these sites of sabkha in the past. In shallow lakes, the lighter layers generally develop during hot, humid periods (with greater water dilution), where there is a significant abundance of living organisms induced precipitation of carbonates. Further, the sequence of 


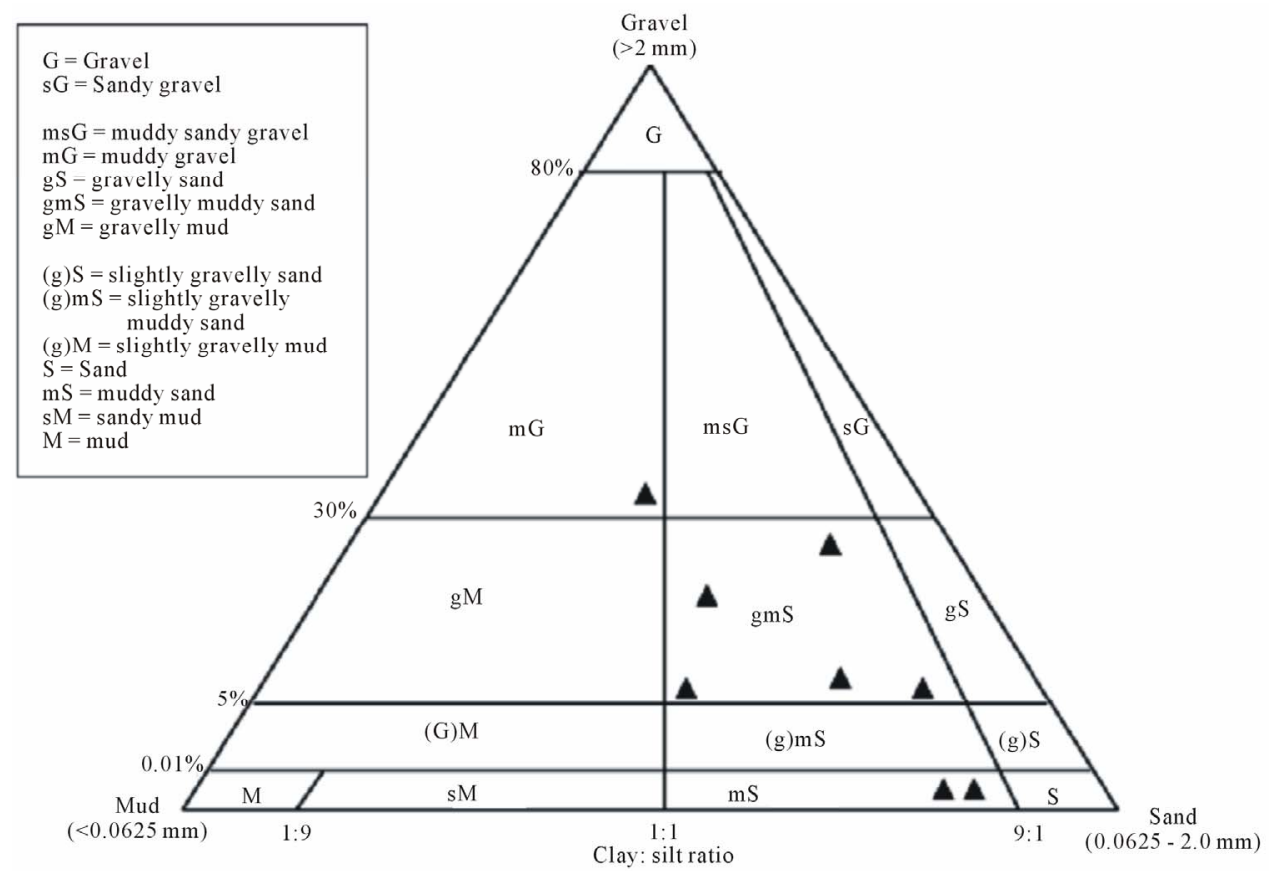

Figure 6. Ternary plots of the analyzed samples.

Phi Units

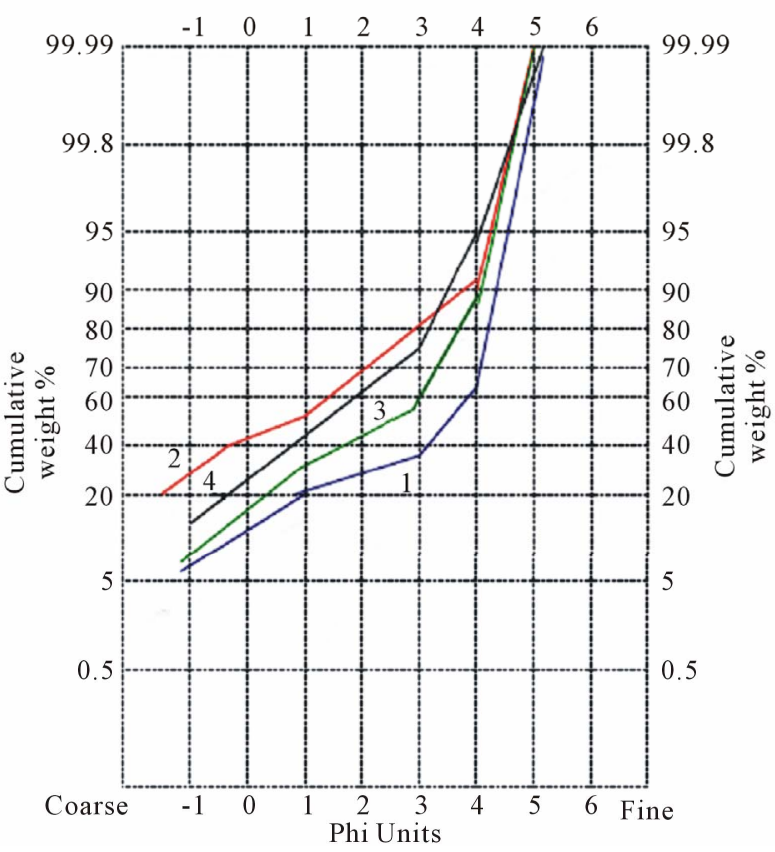

Figure 7. Cumulative shows grain size distribution on southern horizon of the study area. 1: Entrance of Suez; 2: Arab El Dabour viallge; 3: Ahmed Hamdy Tunnel zone; and 4: El Ganayen village.

precipitation of different minerals as well as the sediments contains abundance of carbonates (mainly calcite and dolomite, then aragonite), sulfates (mainly gypsum and anhydrite, then bassanite and bloedite) and chlorides (mainly halite and bischofite). All of these minerals are

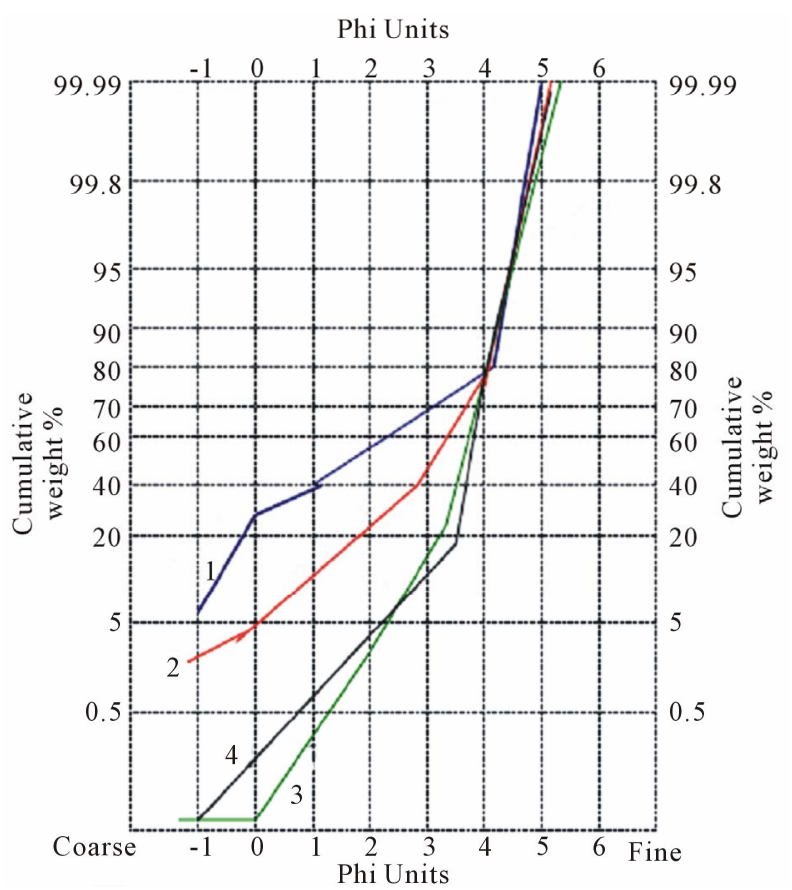

Figure 8. Cumulative shows grain size distribution on northern horizon of the study area. 1: South El Shallufa village; 2: North El Shallufa village; 3: Genifa area; and 4: Entrance of Ismailia.

briefly described below.

The Sulfate minerals (Gypsum and anhydrite): These have clear dominance of sulfates over carbonates. All of these minerals were deposited when $\mathrm{SO}_{4}$ concentration was higher than that of $\mathrm{HCO}^{3-}$ in the brine. Gypsum is 
Table 2. X-ray diffraction data of the studied collected sediments.

\begin{tabular}{ccc}
\hline Locations of sabkha sites & Station sites & Minerals obtained \\
\hline South horizon of the study area & Entrance of Suez & Anhydrite $>$ Gypsum $>$ Bassanite $>$ Quartz $>$ Bloedite \\
El Ganayen village & Quartz $>$ Bassanite $>$ Anhdrite $>$ Halite $>$ Gypsum \\
Arab El Dabour village & Quartz $>$ Bassanite $>$ Gypsum $>$ Bloedite \\
Ahmed Hamdy tunnel zone & Quartz $>$ Anhydrite $>$ Gypsum $>$ Bischofite \\
North horizon of the study area & Quartz $>$ Bassanite $>$ Anhdrite $>$ Gypsum \\
& South of Shallufa viallge & Quartz $>$ Bassanite $>$ Gypsum $>$ Calcite $>$ Halite \\
& Genifa area & Quartz $>$ Kaolinite $>$ Dolomite $>$ Calcite $>$ Bloedite \\
\end{tabular}

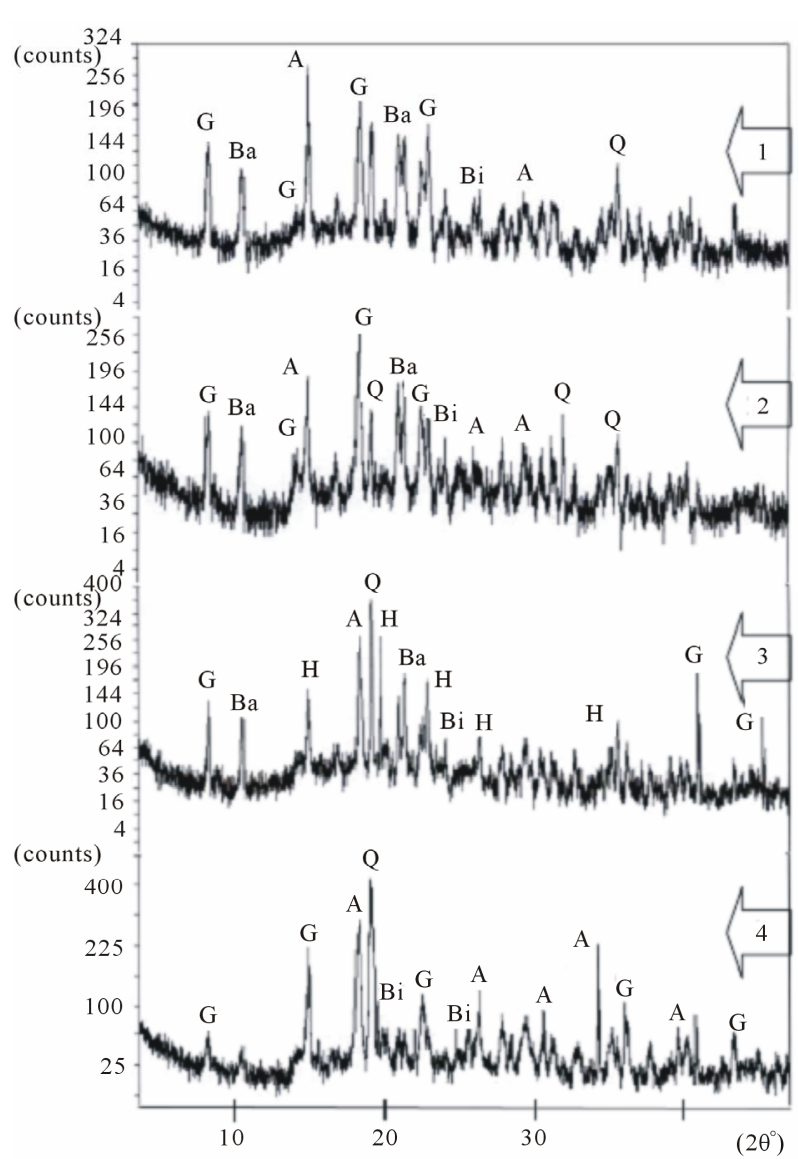

Figure 9. The X-ray diffractograms of sabkha deposits according totheir distribution locations at the southern horizon. Arrows point to characteristic peaks of sabkha site at: 1 = Entrance of Suez; 2 = El Ganayen village; 3 = Arab El Dabour village; 4 = Ahmed Hamdy tunnel zone. $Q=$ Quartz, A = Anhydrite, $\mathbf{G}=$ Gypsum, $\mathbf{C}=$ Calcite, $\mathbf{D}=$ Dolmite, $\mathbf{B i}=$ Bischofite, $\mathbf{B l}=$ Bloedite, $\mathrm{Ba}=$ Bassanite and $\mathrm{K}=$ Kaoline.

the most common sulfate mineral (Plate 3(b)), indicating abundance of $\mathrm{Ca}^{2+}$ ion in the brine; where anhyhydrite is the less of predominance sulfate minerals indicating

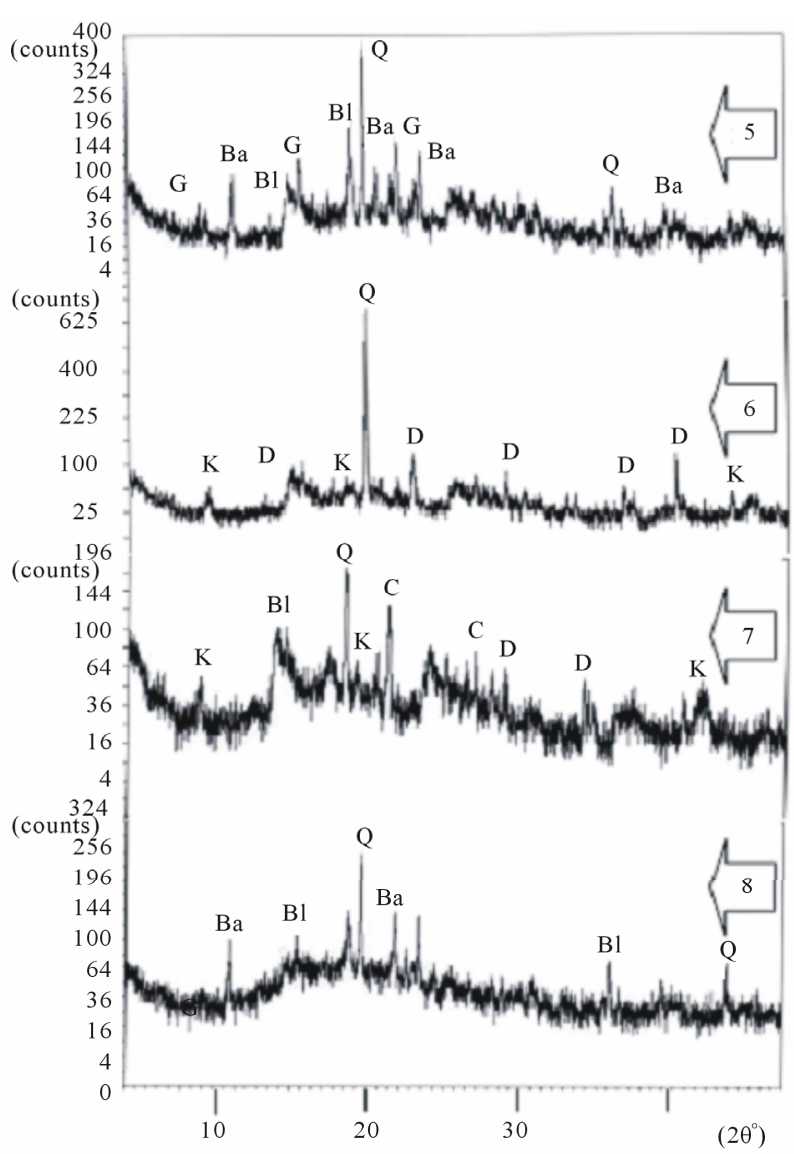

Figure 10. The X-ray diffractograms of sabkha deposits according to their distribution locations at the northern horizon. Arrows point to characteristic peaks of sabkha site at: 5 = South El Shallufa village; 6 = North El Shallufa village; 7 = Genifa area; and 8 = Entrance of Ismailia. $Q=$ Quartz, $\mathrm{A}=$ Anhydrite, $\mathbf{G}=$ Gypsum, $\mathrm{C}=$ Calcite, $\mathbf{D}=$ Dolmite, $\mathbf{B i}=$ Bischofite, $\mathbf{B l}=$ Bloedite, $\mathrm{Ba}=$ Bassanite, and $\mathrm{K}=$ Kaoline.

increased chemical activities of $\mathrm{Na}^{+}$and $\mathrm{K}^{+}$. The formation of anhydrite in the studies sabkha is may be due to both direct crystallization from water and dehydration of 

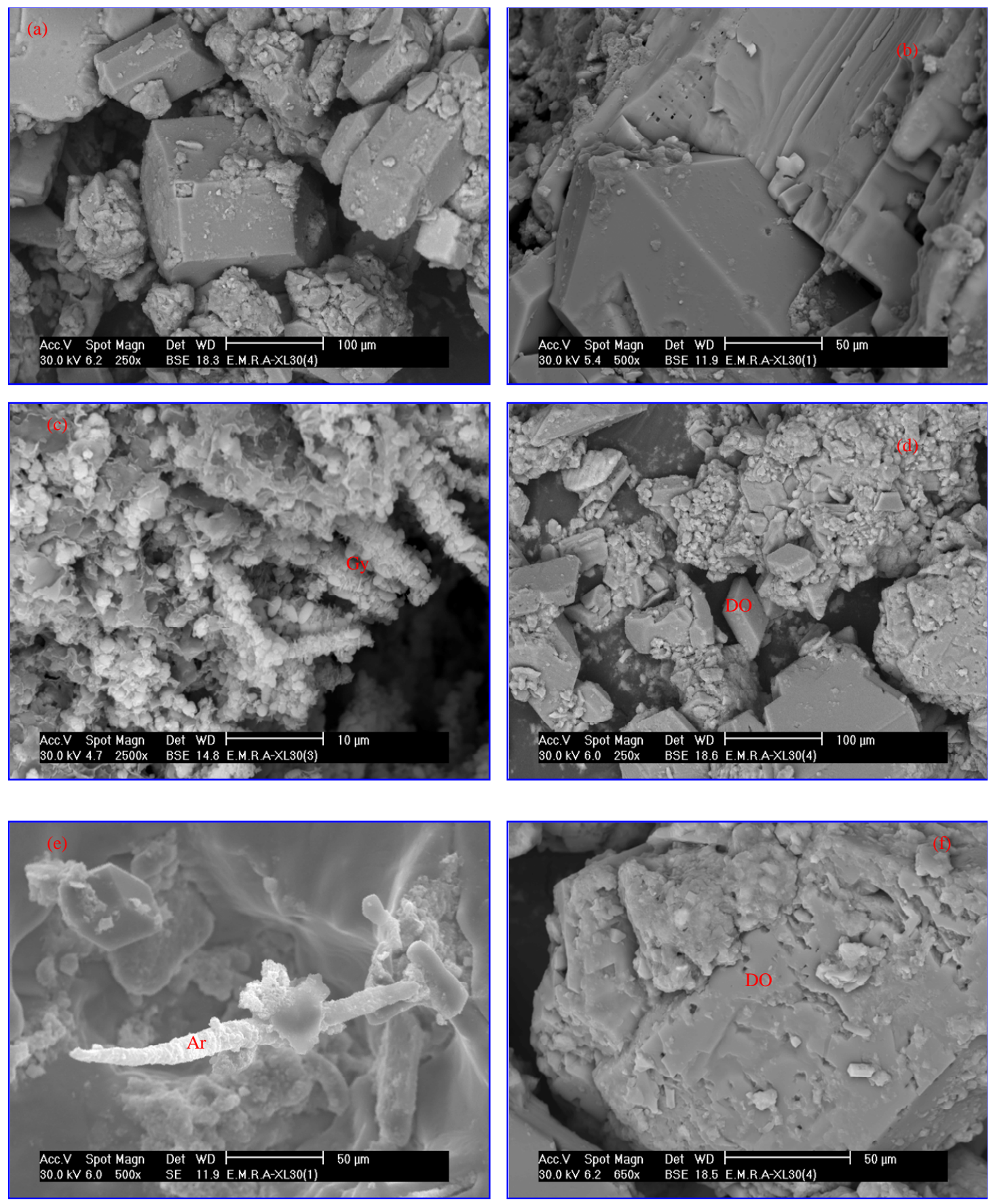

Plate 3. Scanning electron micrographs for selected sediment samples collected from the studied area. SEM image show Quartz (a), the contacts between the gypsum (left) and calcite mineral (right) based on the relative abundance of the minerals (b), small gypsum nodule (c). Dolomite (DO) is found as idiotopic rhombs (d) within the carbonate sediments and an aragonite needle (e), intragranular porosity in dolomite (f).

gypsum. Moreover, anhydrite was found as massive material and in the form of soft white nodules or seams (Plate 3(c)). The presence of bassanite $\left(\mathrm{CaSO}_{4} \cdot 1 / 2 \mathrm{H}_{2} \mathrm{O}\right)$, at sabkha sites represent a highly unstable calcium-sulphate salt, produced by dehydration of gypsum, has been reported by [23] in saline lake deposits in north Mali.

In some samples, bassanite $\left(\mathrm{CaSO}_{4} \cdot 1 / 2 \mathrm{H}_{2} \mathrm{O}\right)$ has been identified in place of gypsum and is interpreted to be dehydration product of gypsum [24], the presence of bassanite between these deposits suggests periods of aridity and very intense insolation. In this special environment, the organic material e.g., fibers, roots (Plate 4(e)) can be recycled by sulphate-reducing bacteria whose activity should favour the precipitation of Mgcalcite and 

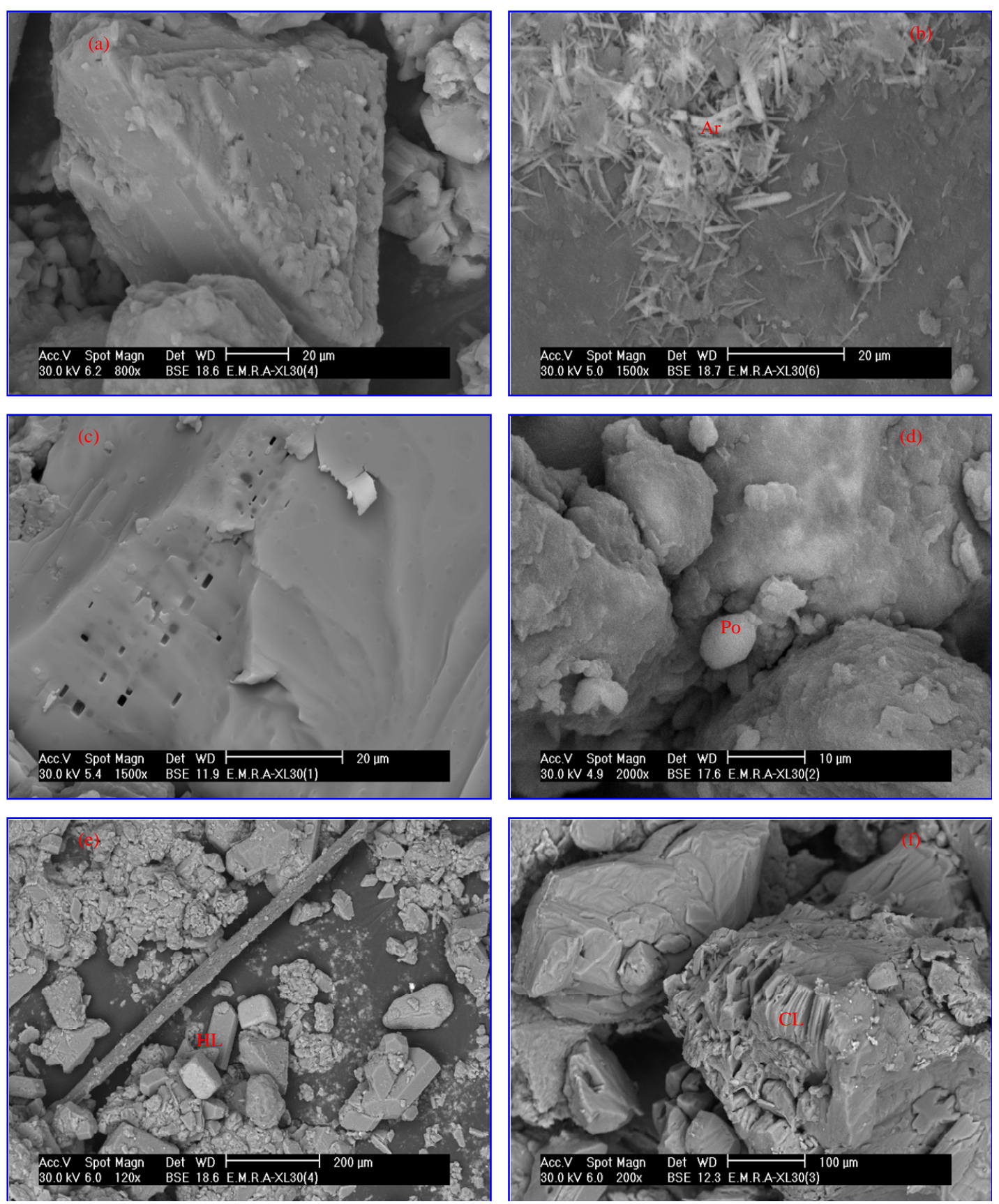

Plate 4. Scanning electron micrographs for selected sediment samples collected from the studied area. SEM image show dolomite (a); an aragonite (Ar) needles (b); and burrowed bacterial mat (c); pollen (Po) grains (d); (HI) halite cube (e); Clay (Cl) minerals with cleavage plane (f) were reported from some of the studied sediments.

Ca-dolomite. Such phenomena are also favoured by the high concentration of sulphate ionsanges, and calcium and magnesium ions. On the contrary bloedite $\left(\mathrm{Na}_{2} \mathrm{SO}_{4}\right.$ $\mathrm{MgSO}_{4}\left(4 \mathrm{H}_{2} \mathrm{O}\right)$ ) has been observed in the same sabkha which decipher the possibility of temporal chandes in $\mathrm{H}_{2} \mathrm{O}$ composition, induced by a variety of factors, including seasonal changes, may account for the coexistence of diverse carbonate phases in the study area of sabkha sediments. This is attributed to, fluid chemistry changes in response to environmental conditions, such as periodic marine flooding and evaporative periods [3,2528]. Some thick gypsum plates were reported from some of the studied sediments.

The Carbonate Minerals (Calcite-Dolomite-Aragonite): These are carbonate- rich sourced from a relatively dilute brine rich in $\mathrm{Ca}^{2+}, \mathrm{Mg}^{2+}, \mathrm{Na}^{1+}, \mathrm{HCO}_{3}$ and $\mathrm{Cl}$. The predominance of calcite suggests a low salinity environment. Dolomite is found as idiotopic rhombs within the 
fossiliferous carbonate sediments (Plate 3(d)). The large size of these dolomite rhombs indicates a higher salinity and Mg-rich brine favoring dolomitization. They are well developed with well-defined boundaries. Furthermore, fine euhedral aragonite needles, are intimately intergrown and concentration in studied sediments (Plate 3(e)). Microporosity is common at grain boundaries and also within dolomite rhombs (Plate 3(f)). Some larger rhombs dolomite crystals show resorption irregular surfaces these can be considered as evidence of dissolution of aragonite and replacement by dolomite (Plate 4(a)). Very small aragonite inclusions persist in larger dolomite grains and irregular boundaries of the dolomite grain, suggest that aragonite has been partially replaced (Plate 4(b)). Dolomite appeared in all the samples as euhedral crystals, dolomite rhombs start to coalesce to form larger aggregates; the euhedral crystals of dolomite precipitated from saline brines and are not detrital. The carbonates become colonized by a bacterial mat and so appear to be driven by infestation of bacteria (Plate 4(c)). The precipitation of carbonated minerals by bacterial mediation in nature and in laboratory experiments have been reported during the last 100 years [20,29-42] obtain precipitation of calcite, aragonite, and high-Mg calcite in the laboratory, and the investigations by [43-45] confirm the relation between dolomite precipitation and bacterial activity and confirm the potentiality of the origin of the carbonates is mainly bio-induced. Some aragonite crystal replaced by dissolution and reprecipitation, both mechanisms occur simultaneously during early diagenesis mainly of sediments at sabkha sites are comprise the carbonate grains are derived either from the disintegration of the skeletal grains including the algal mats or from direct precipitation from shallow marine water as reflected in the type of marine organisms found with these sediments such as Pollen grains (Plate 4(d)).

Chlorides (Halite and Bischofite): These are present in the sabkha sites with spectacular growth of halite in cubic crystals (Plate 4(e)). Generally, the halite in this sediment is a cemented form of detrital grains. Further, the sequence of precipitation of different evaporite minerals. The sediments contain clay minerals (kaolinite and chlorite) (Plate 4(f)). In this special environment, the organic material can be recycled by sulphate-reducing bacteria whose activity should favour the precipitation of Mg-calcite and Ca-dolomite. Such phenomena are also favoured by the high concentration of sulphate ions, and calcium and magnesium ions. Furthermore, the sabkha sediments are commonly dominated by lime mudstones which are very rich in organisms and organic material that adsorbed some minerals at their surface (Plate 5). At all sabkhas sites, the higher concentration of $\mathrm{CaO}$ corresponds to the combination of Gypsum, Calcite, and Dolomite minerals. The high percentage of $\mathrm{MgO}$ is due to the presence of high percentages of pure dolomite and Calcite minerals. The low percentage of $\mathrm{K}_{2} \mathrm{O}$ is due to the absence of pure potassium minerals and presence of high percentage of pure dolomite and calcite minerals.

\subsection{Geochemistry and Paragensis}

Table 2 presents the horizontal distribution of the evaporite facies in the sediments along the district. Carbonate-rich facies sourced from a relatively dilute brine rich in $\mathrm{Ca}^{2+}, \mathrm{Mg}^{2+}, \mathrm{Na}^{+}, \mathrm{HCO}_{3}$ and $\mathrm{Cl}$. The predominance of calcite suggests a low salinity environment. DolomiteAragonite-Bloedite occurs in sabkha deposits but its occurrence is remarkable due to dominance of dolomite. The $\mathrm{CaCO}_{3}$ species present is aragonite instead of calcite, and this horizon also shows high amounts of detrital quartz and feldspar. This facies indicates a higher salinity and Mg rich brine favoring dolomitization. The presence of bloedite (Na-Mg-sulfate) in trace amounts also indicates a high $\mathrm{Mg}^{2+}$ environment. Calcite-Gypsum-Dolomite-Bloedite indicates a slight increase in saliny as compared to the carbonate-rich facies discussed above. $\mathrm{Ca}^{2+}$ is the major cation in the brine being prepitated as calcite, minor dolomite and gypsum. Dolomite-CalciteGypsum-) indicates a brine rich in $\mathrm{Mg}^{2+}$ favoring dolomite precipitation along with gypsum. Gypsum is the most common sulfate mineral, indicating abundance of $\mathrm{Ca}^{2+}$ ion in the sabkha but there is one sabkha where anhydrite is the predominant sulfate minerals indicating increased chemical activities of $\mathrm{Na}^{+}$and $\mathrm{K}^{+}$. In some samples, bassanite $\left(\mathrm{CaSO}_{4}, \mathrm{H}_{2} \mathrm{O}\right)$ has been identified in place of gypsum and is interpreted to be dehydration product of gypsum, perhaps an artifact of sample preparation or precipitation from pore solutions. Significant amounts of dolomite in sabkhas deposits also indicate hypersaline conditions, because dolomitization is due to Mg-rich solutions.

The evaporate-rich horizons possibly developed under conditions when evaporation was high and the groundwater inflow was sufficient $[27,28,46,47]$. The variation in the evaporite mineral assemblage in the sabkhas shows the temporal changes in the chemical environment of the sabkhas. The formation of major evaporite minerals, halite, gypsum and calcite, in this sabkha is controlled by the shallow groundwater, and evaporation. The deposition of gypsum $\left(\mathrm{CaSO}_{4} \cdot 2 \mathrm{H}_{2} \mathrm{O}\right)$ in the sabkha, especially in desert area, is a bed rock mineral. As far as quartz minerals are concerned, their deposition in the inland sabkha basin has resulted from either sediment carried out by intermittent streams from the surrounding areas or mineral deposition by eolian process $[48,49]$. The higher concentration of $\mathrm{CaO}$ corresponds to the presence of gypsum, calcite, and dolomite minerals. $\mathrm{MgO}$ and $\mathrm{K}_{2} \mathrm{O}$ are due to the presence of a high percentage of pure 


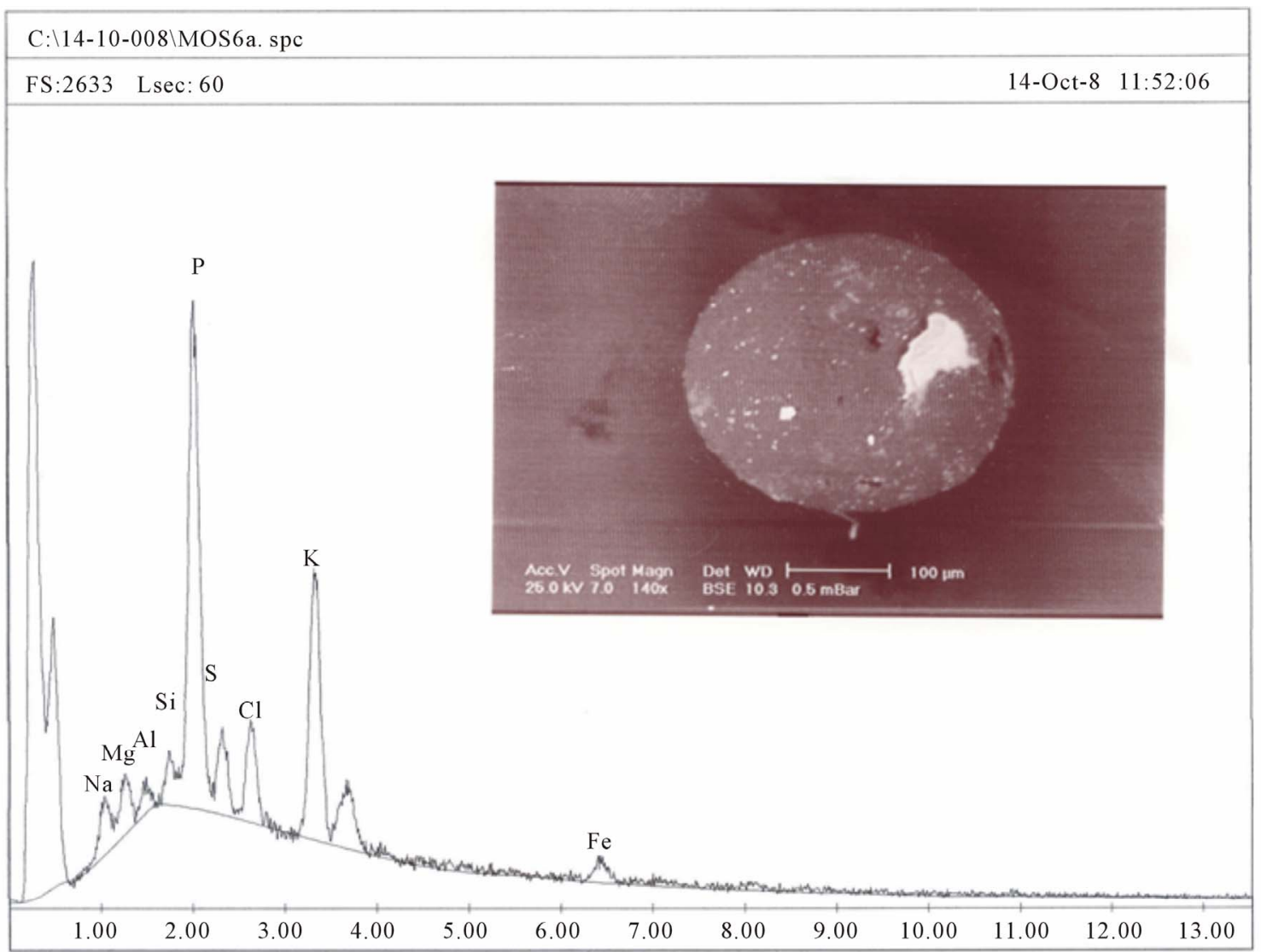

\begin{tabular}{rrrccc} 
Element & wt $\%$ & at $\%$ & Z & A & F \\
\hline NaK & 7.00 & 9.79 & 1.0091 & 0.3728 & 1.0058 \\
MgK & 5.78 & 7.65 & 1.0349 & 0.4468 & 1.0093 \\
AlK & 2.12 & 2.52 & 1.0050 & 0.5259 & 1.0164 \\
SiK & 3.32 & 3.81 & 1.0348 & 0.6375 & 1.0272 \\
PK & 35.30 & 36.68 & 1.0009 & 0.7142 & 1.0130 \\
SK & 7.85 & 7.88 & 1.0272 & 0.5155 & 1.0133 \\
ClK & 9.75 & 8.85 & 0.9823 & 0.5704 & 1.0134 \\
KK & 25.02 & 20.59 & 0.9864 & 0.6979 & 1.0008 \\
FeK & 3.86 & 2.23 & 0.9257 & 0.9310 & 1.0000 \\
Total & 100.00 & 100.00 & & &
\end{tabular}

Plate 5. Scanning electron micrographs for grains with biological components include possible organisms adsorbed some minerals grains.

dolomite and calcite minerals. The low percentage of $\mathrm{K}_{2} \mathrm{O}$ is due to the absence of pure potassium minerals. The high percentages of $\mathrm{SiO}_{2}$ and $\mathrm{Al}_{2} \mathrm{O}_{3}$ are due to the presence of quartz and kaolin along with calcite, dolomite, and gypsum minerals. Where the local water table was at or near the land surface, the clay changed from a light brown color to dark grey color (black when wet) with the smell of dihydrogen sulfide $\left(\mathrm{H}_{2} \mathrm{~S}\right)$, giving the indication of reducing environment. In this sabkha, organic materials can hardly be recognized, although in some places preserved organic matter remains (e.g., fibers, roots, etc.) were observed (Plate 5).

The quartz (25\% - 74\%) plays an important role in in- creasing $\mathrm{SiO}_{2}$ and $\mathrm{Al}_{2} \mathrm{O}_{3}$ in lower facies (silty-sand) as compared at sabkha deposits (e.g. Plate 3(a)). The high percentage of $\mathrm{Al}_{2} \mathrm{O}_{3}$ is due to the presence of high percentages of pure silica minerals. The high percentage of $\mathrm{K}_{2} \mathrm{O}$ is due to the absence of pure potassium minerals and presence of high percentage of pure dolomite and calcite minerals in sabkha deposits During the extremely dry periods, the water table level drops down, leaving the sediment surface uncovered with water for long periods of time. The intense evaporation during these periods causes capillary rise of subterraneous water flows, which generates salinity increase, thus giving rise to precipitation of hard salt facies [25]. 


\section{Conclusions and Recommendations}

Based on the observations and interpretation of the results of mineralogy sabkha sites, the following conclusions and recommendation can be made: The sabkha deposits of the study area exhibit a wide range of minerals which include: The sequence of precipitation of different minerals as well as the sediments contains abundance of quartz and carbonates (mainly calcite and dolomite, then aragonite), sulfates (mainly gypsum and Anhydrite, then bassanite and bloedite) and chlorides (mainly halite and bischofite). Both saline salt and sabkha sediments formation phenomenon has an intensive destructive effect on agricultural lands and village buildings, and infrastructure of newly projects on the study area. There are several factors involved in the formation of salt affecting sediments at sabkhas sites such as parent rocks, texture or lithology, subsurface structural and topography or surface relief, various physiographic feature, saline subsoil water; and shallow water table depths. The X-ray diffraction results showed that, the sediments of the sabkha sites are formed of a mixture of sandmuddy sized and carbonate with evaporite minerals.

Additionally, two main processes were recorded, namely dolomitization and the growth of secondary evaporates. Examination of the algal mats under the SEM indicated that these materials are disintegrating adding micrite-size grains to the sediment budgets. High $\mathrm{SiO}_{2}$ contents correspond to dominance of quartz and other clastic and terrigenous minerals, while variable $\mathrm{CaO}$ and/or $\mathrm{MgO}$ contents account for carbonates. Dolomite also was reported from some of collected sediments and believed to be resulted from mixing freshwater with seawater in the mixing zone. The distribution of the main elements in the water insoluble fraction generally reflects the mineralogy of clastic sediments and carbonates. The involvement of the geologist in the planning and management of urban area is becoming increasingly important. Moreover, detailed the physiographic feature studies should be carried on study area and its environs to established data base and to get better understanding of sabkhas soil occurrence and effects factors controlling. Detailed geologic setting information might be collected and analyzed before taking decision of urban planning and development of an area.

\section{REFERENCES}

[1] W. Sanford and W. Wood, "Hydrology of the Coastal Sabkhas of Abu Dhabi, United Arab Emirates,” Hydrogeology Journal, Vol. 9, No. 4, 2001, pp. 358-366. doi:10.1007/s100400100137

[2] W. Akili, "On Sabkha Sands of Eastern Saudi Arabia," Proceedings of the Geotechnical Problems in Saudi Arabia Symposium, Riyadh, 11-13 May 1981, pp. 775-793.
[3] W. Fookes and M. Rice, "The Influence of Ground and Groundwater Chemistry on Construction in the Middle East,” Quarterly Journal of Engineering Geology London, Vol. 18, No. 2, 1985, pp. 101-128. doi:10.1144/GSL.QJEG.1985.018.02.01

[4] G. Evans, "Coastal and Near Shore Sedimentation: A Comparison of Clastic and Carbonate Deposition,” Proceedings of Geological Society of London, Vol. 81, No. 3, 1970, pp. 493-508. doi:10.1016/S0016-7878(70)80010-4

[5] J. Hansom and D. McGlashan, "Scotland's Coast Understanding Past and Present Processes for Sustainable Management," Scottish Geographical Journal, Vol. 120, No. 1-2, 2004, pp. 99-116. doi:10.1080/00369220418737195

[6] A. Abdallah and F. Abdel Hady, "Geology of Sadat Area, Gulf of Suez,” Journal of Geology, Vol. 10, No. 1, 1966, pp. 1-22.

[7] E. El Shazly, M. Abdel Hady, A. Salman, M. Morsy, M. El Rakaiby, I. El Assy, A. Kamel, W. Meshref, A. Ammar and M. Meleik, "Geological Investigations of the Suez Canal Zone,” Academy of Scientific Research and Technology, Cairo, 1975, p. 54.

[8] M. El Ebiary, "Shallow Subsurface Geological and Geophysical Studies in Lake Temsah, Suez Canal Area, Egypt,” M.Sc. Thesis, Faculty of Science, Tanta University Egypt, Tanta, 1981, 200p.

[9] H. Afify, "Studies on Water Resources and Pollution in Some Areas of the Suez Canal Province, Egypt,” M.Sc. Thesis, Faculty of Science, Suez Canal University, Ismailia, 2002, 189p.

[10] F. El Fawal, "Sedimentology and the Quaternary Southwest of Ismailia and Its Chronostratigraphy West of the Suez Canal," Proceedings of 3rd Conference Geology of Sinai and Development, Ismailia, 1992, pp. 141-152.

[11] H. Aboulela, "A Study on the Tectonic Activity and Seismicity in the Suez Canal Region,” M.Sc. Thesis, Faculty of Science, Suez Canal University, Ismailia, 1994, 133p.

[12] H. Geriesh, "Improvement of Drinking Water Quality in the New Villages, East of Suez Canal Navigation Route, Sinai Peninsula, Egypt. Using Artificial Ground Water Recharge Techniques,” Al-Azhar Bulletin of Science, Vol. 15, 1999, pp. 37-54.

[13] E. El Shazly, M. Abdel Hady, M. El Shazly, M. El Ghawaby, J. El Kassas, A. Salman and M. Morsy, "Geological and Ground Water Potential Studies of El Ismailia Master Plan Study Area,” Academy of Scientific Research and Technology, Cairo, 1975, p. 45.

[14] F. Ramadan, "Sedimentological Studies on the bottom Sediments of the Suez Canal,” M.Sc. Thesis, Faculty of Science, Zagazig University, Zagazig, 1984, 185p.

[15] M. Omaran, "Geological Studies of Shabraweet Area, Suez Canal, Egypt,” M.Sc. Thesis, Faculty of Science, Suez Canal University, Ismailia, 1989, 135p.

[16] H. Geriesh, "Hydrogeological Investigations of West Ismailia Area, Egypt,” M.Sc. Thesis, Faculty of Science, Suez Canal University, Ismailia, 1989, 210p.

[17] R. Said, “The Geology of Egypt,” Elsevier Pub Co., Amsterdam, 1962, p. 377. 
[18] A. Abdallah, M. Abdel Aal and M. Hussein, "Integrated Surface and Subsurface Structural Study of the Area between Mediterranean and Eastern Desert, Egypt,” EGPC's Exploration \& Production Conference, Cairo, 1998, pp. 1-12.

[19] M. El Masry, “Geology and Mineralogy of Evaporites and Evaporite-Bearing Sediments in the Bitter Lakes, Egypt,” M.Sc. Thesis, Faculty of Science, Suez Canal University, Ismailia, 1992, p. 85.

[20] R. Folk, "Petrology of Sedimentary Rocks," Hempill Publishing Co., Austin, 1974, p. 182.

[21] G. Brown, "The X-Ray Identification and Crystal Structure of Clay Minerals,” Mineral Society, London, 1961, $544 \mathrm{p}$.

[22] W. Krumbein and F. Pettijohn, "Manual of Sedimentology petrography,” Appleton-Century-Crofts, Inc., New York, Prentice-Hall, Inc., 1938, 549p.

[23] F. Mees, "Petrological Studies of Saline Deposits of a Perennial Saline Lake and a Dry Lake Basin, and of Calcareous Deposits of Small Freshwater Basins,” Ph.D. Thesis, University of Ghent, Ghent, 1998.

[24] D. Shearman, "Halite in Sabkha Environments,” In: W. E. Dean and B.C. Schreiber, Eds., Marine Evaporites, SEPM, Tulsa, 1978, pp. 430-442.

[25] A. Perez, A. Luzon, R. Roc, M. Soria, M. Mayayo and J. Sanchez, "Sedimentary Facies Distribution and Genesis of a Recent Carbonate-Rich Saline Lake: Gallocanta Lake, Iberian Chain, NE Spain,” Sedimentary Geology, Vol. 148, No. 1-2, 2002, pp. 185-202. doi:10.1016/S0037-0738(01)00217-2

[26] F. Fayazi, "Evaporates of the Howze Soltan Lake Basin,” Ph.D. Thesis, University of East Anglia, Norwich, 1991, 185p.

[27] M. Rosen, “Sedimentological and Geochemical Constraints on the Hydrologic Evolution of Bristol Dry Lake, California, USA,” Paleogeography and Paleoecology, Vol. 84, No. 1-4, 1991, pp. 229-257. doi:10.1016/0031-0182(91)90046-T

[28] M. Rosen, "The Importance of Groundwater in Playas: A Review of Playa Classifications and the Sedimentology and Hydrology of Playas," Geological Society of America Special Publication, Vol. 289, 1994, pp. 1-18.

[29] G. Nadson, "Die Mikrooganismen als Geologische Faktoren,” Botanisches Centralblatt, Vol. 96, 1903, pp. 591593.

[30] G. Nadson, "Beitrag zur Kenntnis der Bakteriogenen Kalkablagerungen,” Archiv fuer Hydrobiologie, Vol. 19, 1928, pp. 154-164.

[31] W. Bavendam, "Die Mikrobiologische Kalkfällung in der Tropischen See,” Archiv fuer Mikrobiologie, Vol. 3, 1932, pp. 205-216.

[32] P. Bush, "Some Aspects of the Diagenetic History of the Sabkha in Abu Dhabi, Persian Gulf,” In: B. H. Purser, Ed., The Persian Gulf, Springer, Berlin, 1973, p. 265.

[33] W. Krumbein, "On the Precipitation of Aragonite on the Surface of Marine Bacteria,” Naturwissenschaften, Vol. 61, No. 4, 1974, p. 167. doi:10.1007/BF00602591
[34] W. Krumbein, "Photolithographic Chemoorganotrophic Activity of Bacteria and Algae as Related to Beach Rock Formation and Degradation (Gulf of Aqaba, Sinai),” Geomicrobiology Journal, Vol. 1, No. 2, 1979, pp. 139-198. doi:10.1080/01490457909377729

[35] W. Krumbein and F. Pettijohn, "Manual of Sedimentology Petrography,” Appleton-Century-Crofts, Inc., New York, 1958, 549p.

[36] M. Dames, "Subsurface Surveys for Industrial Complex at Yanbu,” Unpublished Technical Report, 1976, p. 960.

[37] H. Chafetz and R. Folk, "Travertines: Depositional Morphology and the Bacterially Constructed Constituents," Journal of Sedimentary Petrology, Vol. 54, No. 1, 1984, pp. 289-316.

[38] S. Castanier, "Microbiogéologie: Processes et Modalités de la Carbonatogenèse Bactérienne,” Ph.D Thesis, University of Nantes, Nantes,1987, p. 255.

[39] J. Adolphe, A. Hourimeche, F. Loubière, J. Paradas and F. Soleilhavoup, "Les Formations Carbonatées d'Origine Bacterienne. Formations Continentales d'Afrique du Nord," Société Géologique de France Bulletin, Vol. 8, 1989, pp. 52-62.

[40] H. Chafetz, "Bacterially Induced Precipitates of Calcium Carbonate and Lithification of Microbial Mats,” In: W. Krumbein, M. Paterson and J. Lucas, Eds., Bioestablization of Sediments, Bibliotheks und Informations System der Universität Oldenburg, Oldenburg, 1994, pp. 149-163.

[41] A. Kendall and G. Harwood, "Marine Evaporites: arid Shorelines and Basins,” In: H. G. Reading, Ed., Sedimentary Environments: Processes, Facies and Stratigraphy, Blackwell Science, London, 1997, pp. 281-324.

[42] S. Castanier, J. Perthuisot, M. Matrat and J. Morvan, “The Salt Ooids of Berre Salt Works (Bouches du Rhone, France); The Role of Bacteria in Salt Crystallization," Sedimentary Geology, Vol. 125, No. 1-2, 1999, pp. 9-21. doi:10.1016/S0037-0738(98)00144-4

[43] C. Vasconcelos, J. McKencie, D. Bernasconi, A. Gruyic and J. Tien, "Microbial mediation as a Possible Mechanism for Natural Dolomite Formation at Low Temperatures,” Nature, Vol. 377, No. 6546, 1995, pp. 220-222. doi:10.1038/377220a0

[44] C. Vasconcelos and J. McKencie, "Microbial Mediation of Modern Dolomite Precipitation and Diagenesis under Anoxic Conditions (Lagoa Vermeha, Rio de Janeiro Brazil),” Journal of Sedimentary Research, Vol. 67, 1997, pp. 378-391.

[45] C. Kendall, A. Patrick and D. Skipwith, "Recent Algal Mats of a Persian Gulf Lagoon,” Journal of Sedimentary Petrology, Vol. 38, No.4, 1968, pp. 1040-1058.

[46] A. Kendall and G. Harwood, "Marine Evaporites: Arid Shorelines and Basins,” In: H. G. Reading, Ed., Sedimentary Environments: Processes, Facies and Stratigraphy, Blackwell Science, London, 1997, pp. 281-324.

[47] R. Kalin and T. Elliot, "Sustainability of groundwater Resources in Water-Scarce Regions: From Micro- to MacroScales,” Natural Resources \& Environment Research Institute, King Abdulaziz City for Science and Technology, Kingdom of Saudi Arabia, 2001, p. 56. 
[48] K. Glennie, “Desert Sedimentary Environments,” In: D. Henningsen, Ed., Developments in Sedimentology, Elsevier, Amsterdam, 1969.

[49] C. Young and H. Krouse, “The Origin of Sulphates in
Castleguard Cave, Columbia Ice Fields, Canada,” In N. Cauer and S. Chaudhuri, Eds., Isotopes in the Sedimentary Cycle, Elsevier Science Publishers, Amsterdam, Vol. 65, 1987, pp. 427-433. 